Article

\title{
Resistance of ETICS with Fire Barriers to Cyclic Hygrothermal Impact
}

\author{
Rosita Norvaišienè $^{1, *(\mathbb{D}}$, Paweł Krause ${ }^{2}\left(\mathbb{D}\right.$, Vincent Buhagiar ${ }^{3}$ and Arūnas Burlingis ${ }^{1}$ \\ 1 Institute of Architecture and Construction, Kaunas University of Technology, LT-44405 Kaunas, Lithuania; \\ arunas.burlingis@ktu.lt \\ 2 Faculty of Civil Engineering, Silesian University of Technology, 44-100 Gliwice, Poland; \\ Pawel.Krause@polsl.pl \\ 3 Department of Environmental Design, Faculty for the Built Environment, University of Malta, \\ MSD 2080 Msida, Malta; vincent.buhagiar@um.edu.mt \\ * Correspondence: rosita.norvaisiene@ktu.lt; Tel.: +370-603-00508
}

Citation: Norvaišienè, R.; Krause, P.; Buhagiar, V.; Burlingis, A. Resistance of ETICS with Fire Barriers to Cyclic Hygrothermal Impact. Sustainability 2021, 13, 9220. https://doi.org/ $10.3390 /$ su13169220

Academic Editors: Bartosz Michałowski and Chi-Ming Lai

Received: 15 June 2021

Accepted: 13 August 2021

Published: 17 August 2021

Publisher's Note: MDPI stays neutral with regard to jurisdictional claims in published maps and institutional affiliations.

Copyright: (c) 2021 by the authors. Licensee MDPI, Basel, Switzerland. This article is an open access article distributed under the terms and conditions of the Creative Commons Attribution (CC BY) license (https:// creativecommons.org/licenses/by/ $4.0 /)$.

\begin{abstract}
The article presents the results of a set of hygrothermal experiments of an external wall insulated with an ETICS. As an add-on to previous studies, thermal insulation in the form of polystyrene with an additional horizontal strip of mineral wool was used. Laboratory tests were carried out in accordance with ETAG 004. The ETICS test rig was composed of combustible expanded polystyrene foam (EPS) and horizontal strips of noncombustible mineral wool (MW) fire barriers over windows. The physical and mechanical properties of four types of finishing renders (without an additional reinforcement mesh in base coat of the fire barriers) were analyzed across full hygrothermal cycles in a climate chamber. Temperature sensors were mounted onto different ETICS layers to collect thermal data during the weathering. The testing of ETICS regarding their hygrothermal performance revealed that there were no visible defects on any renderings and over the junctions depending on the type of used insulation materials. Results also showed that the joints of EPS and MW have approximately half of their bond strength from polystyrene strength.
\end{abstract}

Keywords: ETICS; EPS; MW; fire barriers; hard-body impact; hygrothermal behaviour

\section{Introduction}

External thermal-insulation composite systems (ETICS) significantly reduce energy consumption for new and existing buildings, and extend the service life of the external walls. By preventing greenhouse-gas emissions, ETICS also improve thermal indoor comfort and hygiene standards [1-4]. The effectiveness of ETICS depends on their physical and mechanical properties, and the quality of system installation [1-7]. Defects often occur as a consequence of detailing shortfalls or poor workmanship. The finishing coat of ETICS is the most vulnerable layer exposed to climatic factors [8-11]. Precipitation, solar radiation, and temperature differences may negatively impact the thermal-insulation system, causing a broad range of types of damage [1,5-7,12-16].

In spite of the thermal advantages of ETICS, their relatively low cost, and ease of application, combustible insulation materials used in ETICS have raised serious fire-safety issues [9]. In order to prevent the fast spread of fire, different provisions can be made, such as barriers of noncombustible material such as mineral wool around the openings, and horizontal isolation barriers around the buildings between different floors $[4,7,9]$. Parallel to the emergence of new recommendations, there are various technical doubts about the possible negative effects of such a combination [6-8,16-19]. One is the presumption that there may be cracks in the reinforcing and rendering layers due to the different thermal expansion of materials under the influence of external factors; another possibility is the discoloration of the facade, associated with the different moisture-absorption rates of thermal-insulation materials [6-8]. In some countries, there are guidelines for implementation of an additional 
fiberglass mesh (identical to that of the rendering system in the current part) on fire barrier strips, overlapping at least $150 \mathrm{~mm}$ on either side of the strip [20]. Moreover, different countries still have different ETICS requirements and solutions for fire safety [9]. The rapid development of construction technologies, together with emerging new guidelines or recommendations, indicates the need for the practical verification of adopted solutions.

On this subject, various research papers were published [1-20]; however, there is practically no information about the performance of two different thermal-insulation materials during hygrothermal testing. Since fire barriers are an integral part of ETICS, it is very important to know what kind of testing method is being used to ensure that the building occupants can be kept safe and healthy. Therefore, results from water-absorption and mechanical-resistance testing of ETICS are presented. The aim of this research is to estimate the impact of different thermal-insulation types (i.e., EPS and MW as the fire barrier) on the hygrothermal behaviour of ETICS according to ETAG 004. Moreover, the scope is to check the possibility of appearance of cracks in the joints between EPS and MW without additional mesh covering on the fire barrier during hygrothermal testing.

\section{Methodology and Materials}

A silicate brick wall was constructed ( $3.0 \mathrm{~m}$ wide by $2.2 \mathrm{~m}$ high) with installed ETICS panels (Figure 1) in accordance with 5.1.3.2.1 ETAG 004 [19]. Four different types of thermalinsulation systems were applied on the wall, namely, with acrylic, silicate, mineral, and silicone finishing coats (of whitish color). Mineral rendering was painted with silicone paint. The thickness of the basecoat was 3-5 mm. In order to examine the worst-case scenario of ETICS, $1 \mathrm{~mm}$ thickness finishing coats were selected except for a $2 \mathrm{~mm}$ thickness mineral coat. Thermal-insulation boards were mechanically fixed with plastic anchors $\left(4 \mathrm{pcs} . / \mathrm{m}^{2}\right)$ with supplementary adhesive.

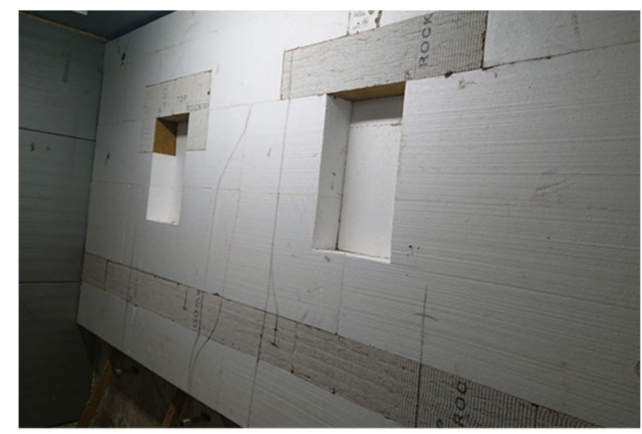

(a)

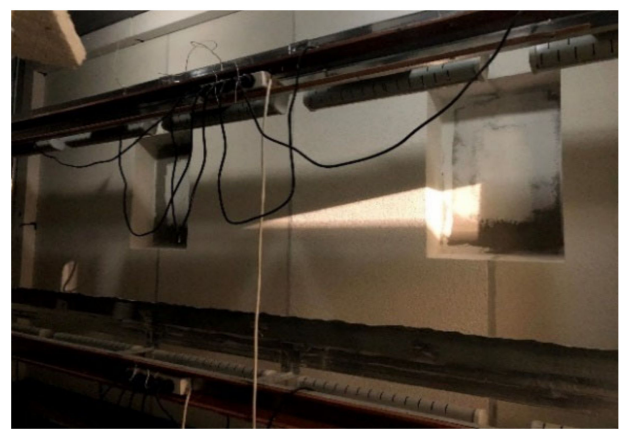

(b)

Figure 1. (a) EPS thermal insulation with mineral wool fire barriers; (b) test rig with 4 types of plastering during the test.

Expanded polystyrene EPS70 (140 mm thickness) was used as an insulation material with mineral wool as a fire barrier (140 $\mathrm{mm}$ thickness). The general characteristics of thermal insulation indicated by the producers are shown in Table 1.

Table 1. General characteristics of thermal insulation.

\begin{tabular}{cccccc}
\hline Insulation & $\begin{array}{c}\text { Vapour Diffusion } \\
\text { Resistance Factor }(\mu)\end{array}$ & Density, $\mathbf{k g} / \mathbf{m}^{\mathbf{3}}$ & $\begin{array}{c}\text { Thermal } \\
\text { Conductivity, } \\
\mathbf{W} /(\mathbf{m} \cdot \mathbf{K})\end{array}$ & $\begin{array}{c}\text { Water Absorption } \\
\left(\mathbf{W}_{\mathbf{2 4}}\right), \mathbf{k g} / \mathbf{m}^{\mathbf{2}}\end{array}$ & $\begin{array}{c}\text { Compressive } \\
\text { Strength, } \mathbf{k P a}\end{array}$ \\
\hline MW & 1 & 136 & 0.036 & $\leq 3$ & $\geq 20$ \\
EPS & 30 & 14.5 & 0.039 & $\leq 0.04$ & $\geq 70$ \\
\hline
\end{tabular}

General characteristics of all finishing coats: density, $1.8-1.9 \mathrm{~kg} / \mathrm{dm}^{3}$; thermal conductivity, $0.70(\mathrm{~W} / \mathrm{m} \cdot \mathrm{K})$; long-term water absorption, $0.1-0.5 \mathrm{~kg} / \mathrm{m}^{2}$; water-vapour diffusion resistance factor, $15 \div 150$. 
The same mineral base coat together with a reinforcing mesh was applied to all ETICS without additional reinforcement mesh on the fire barriers. The horizontal strip of mineral wool (200 mm width) was installed in the lower part of the rig and above the openings. ETICS were installed according manufacturer's instructions; this was submitted to laboratory conditions (temperature $20 \pm 5^{\circ} \mathrm{C}$ ) for 4 weeks. During the first 20 days, the rig was subjected to 80 heat-rain cycles and 5 heat-cold cycles:

Heat-rain cycling:

- $\quad$ heating to $70{ }^{\circ} \mathrm{C}$ and maintaining this temperature at $70 \pm 5{ }^{\circ} \mathrm{C}$ and relative humidity at the level of $10-30 \%$ for $2 \mathrm{~h}$ (3 $\mathrm{h}$ in total);

- $\quad$ sprinkling with water at a temperature of $15 \pm 5{ }^{\circ} \mathrm{C}$ in the amount of $1 \mathrm{~L} / \mathrm{m}^{2}$ for $1 \mathrm{~h}$ and leaving the rig for a period of $2 \mathrm{~h}$.

Heat-cold cycling:

- $\quad$ heating to $50 \pm 5{ }^{\circ} \mathrm{C}$ and $30 \% \mathrm{RH}$ for $7 \mathrm{~h}$;

- freezing to $-20 \pm 5{ }^{\circ} \mathrm{C}$ for $14 \mathrm{~h}$.

In order to follow the temperature in different layers of ETICS and in the junction between EPS and MW, 38 pieces of temperature sensors were installed (see Figure 2). Duplex insulated Omega TT-T-30 T-type thermocouples were used. Measuring ranged from -200 to $350{ }^{\circ} \mathrm{C}$, and accuracy was $\pm 1.0^{\circ} \mathrm{C}$ or $\pm 0.75 \%$. Temperature sensors were installed at each of the assumed heights. One was at the junction of the thermal insulation with the structural layer, and the other in the middle of the thermal-insulation thickness. This is depicted in Figure 2. The rig was divided into four vertical areas (dotted lines). Pink lines reflect the EPS boards, and green areas the mineral wool.
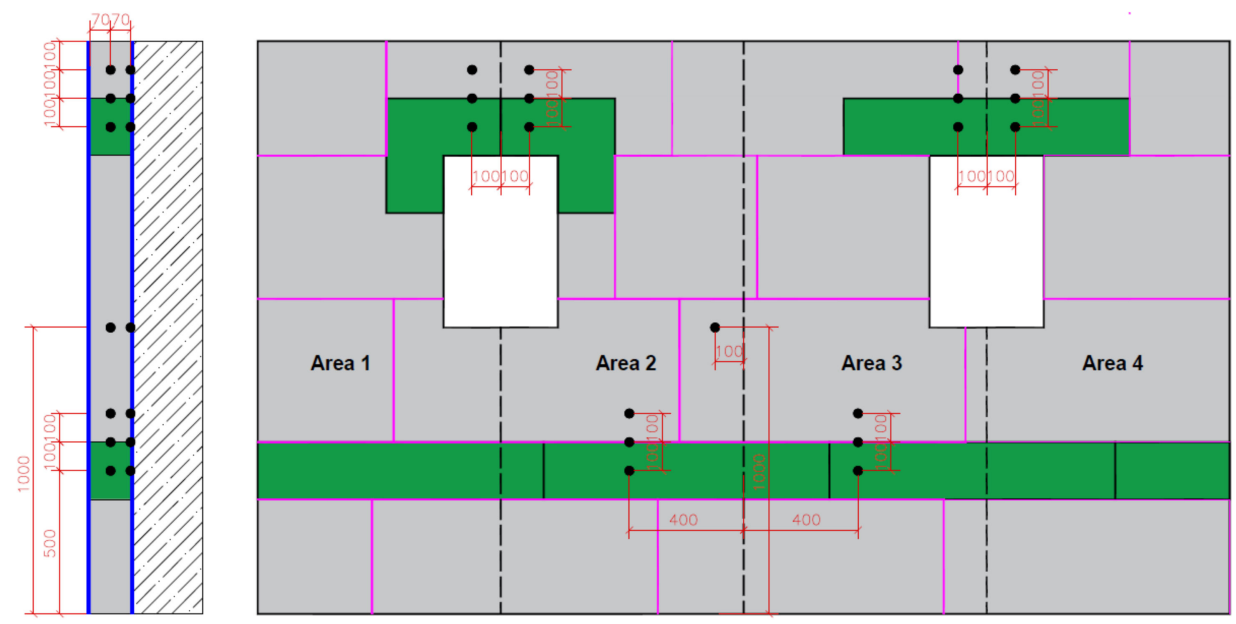

Figure 2. Temperature-sensor placement, cross-section, and elevation (area 1, acrylic render; area 2, silicate render; area 3, mineral render; area 4, silicon render).

After going through the weathering, the specimens' moisture contents mass by mass of thermal insulation directly under the rendering were determined according to EN ISO 12570 on the hygrothermal performance of building materials and products. Moisture content was determined by drying at elevated temperature.

Furthermore, hard-body impact (as per ETAG 004 5.1.3.2.1 [19]) and bond-strength (as per ETAG 004 5.1.4.1.1 [19]) tests were performed. The test was performed with adhesion tester CONTROLS 58-C0215/T (Figure 3). The plates were pulled at a speed of 1 to $10 \mathrm{~mm} / \mathrm{min}$. Individual and average values were recorded and are expressed in $\mathrm{MPa}$. The pull of the test was performed at $18 \pm 2{ }^{\circ} \mathrm{C}$ at $\mathrm{SD}=50 \pm 5 \%$. 


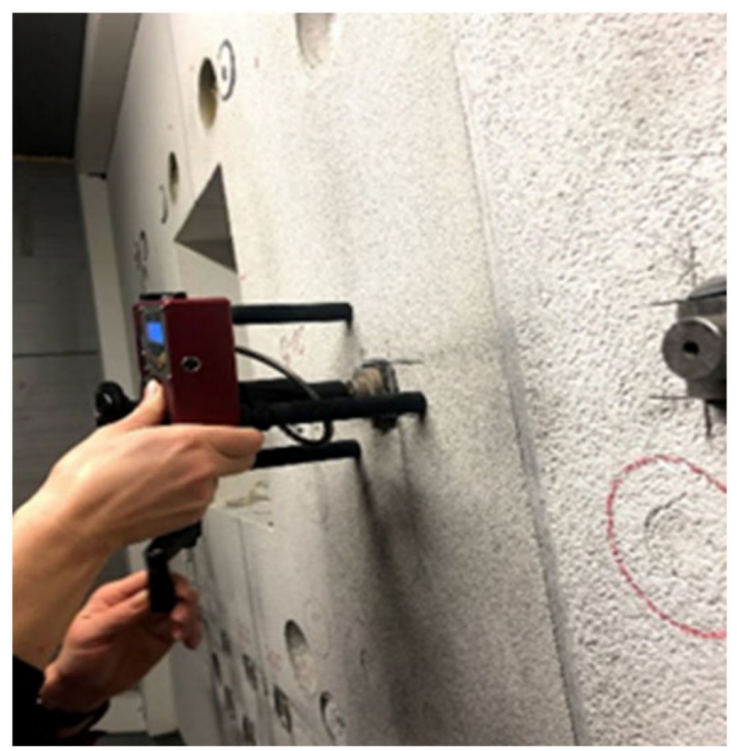

Figure 3. Testing of the bond strength of ETICS.

\section{Results and Discussion}

Following the conclusion of the heat-rain and heat-cold cycles, on the basis of macroscopic tests, no irregularities were found on all analysed types of thin-layer rendering surfaces. No cracks, scratches, or hairline superficial crevasses of any kind were observed; this implies that the joints of the EPS/MW remained intact, suggesting that there was no water penetration into the insulation layer (Figure 4). Therefore, the above-mentioned ETICS are resistant to hygrothermal cycles neglecting to absence of additional reinforcement mesh over MW fire barriers.

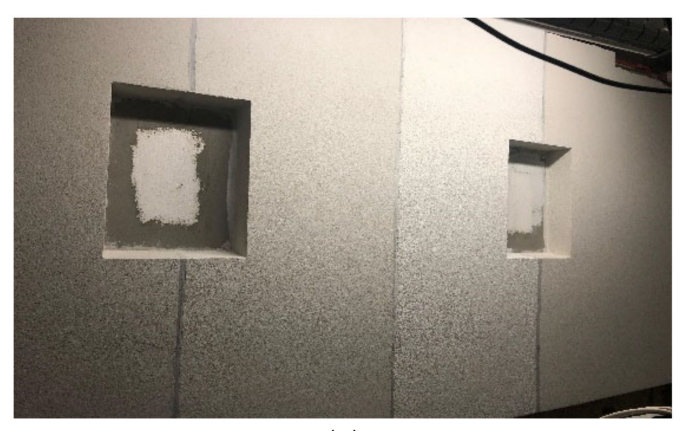

(a)

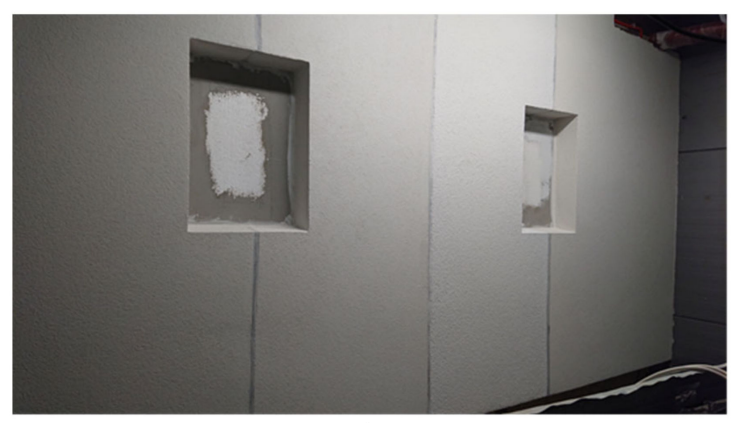

(b)

Figure 4. Photo fixation set of the ETICS (a) before and (b) after testing.

\subsection{Moisture Transfer}

The obtained moisture-testing results show that the actual moisture content slightly varied depending on the type of applied render and used thermal insulation. The calculation of mass by mass-moisture content for individual types of render and thermal insulation after 80 heat-rain cycles showed different results. With EPS thermal insulation, the highest moisture level was recorded for ETICS with a silicone render $(w=2.3 \%)$. In the case of mineral wool, the highest achieved value was for acrylic and silicone render $(\mathrm{w}=0.5 \%)$ (Table 2$)$.

\subsection{Temperature Profile}

When thermocouple data were analysed, the temperature profile across the whole depth of thermal-insulation layers, and at the interface of the different layers during 
the hygrothermal cycle, remained similar, and did not depend on the type of thermalinsulation layer. The typical profile of temperature variations is given in Figure 5 (ETICS no. 2 / silicate). The trend of temperature differences at different measuring locations on surface finishes and in the middle of insulating layer are very similar; these had a rectangular plateau-wave shape. The temperature at the masonry base ranged from 26 to $27^{\circ} \mathrm{C}$. The temperature in the middle of the thermal-insulation materials (7-8 cm from the surface) ranged from 26 to 40 and $42.5^{\circ} \mathrm{C}$. Temperature at the junction of EPS/MW had a value closer to that of the temperature in the middle of MW than to that of the temperature in the middle of EPS. The heterogeneity of the material structure can cause local thermal anomalies. Temperature differences on the EPS and base-wall interface, and in the junction of EPS $/ \mathrm{MW}$ were insignificant and amounted to $\Delta \mathrm{t}_{\text {average }}=0.2{ }^{\circ} \mathrm{C}$.

Table 2. Moisture content of thermal insulation right under finishing coat (sample thickness, $30 \mathrm{~mm}$ ) of the ETICS after testing in the ageing chamber.

\begin{tabular}{ccc}
\hline $\begin{array}{c}\text { System or Kind of } \\
\text { Rendering }\end{array}$ & \multicolumn{2}{c}{ Moisture Content Mass by Mass, $\%$} \\
\cline { 2 - 3 } & EPS & MW \\
\hline ETICS no. 1/acrylic & 1.2 & 0.5 \\
\hline ETICS no. 2/silicate & 1.1 & 0.1 \\
\hline $\begin{array}{c}\text { ETICS no. 3/mineral/silicone } \\
\text { paint }\end{array}$ & 1.7 & 0.1 \\
\hline ETICS No. 4/silicone & 2.3 & 0.5 \\
\hline
\end{tabular}

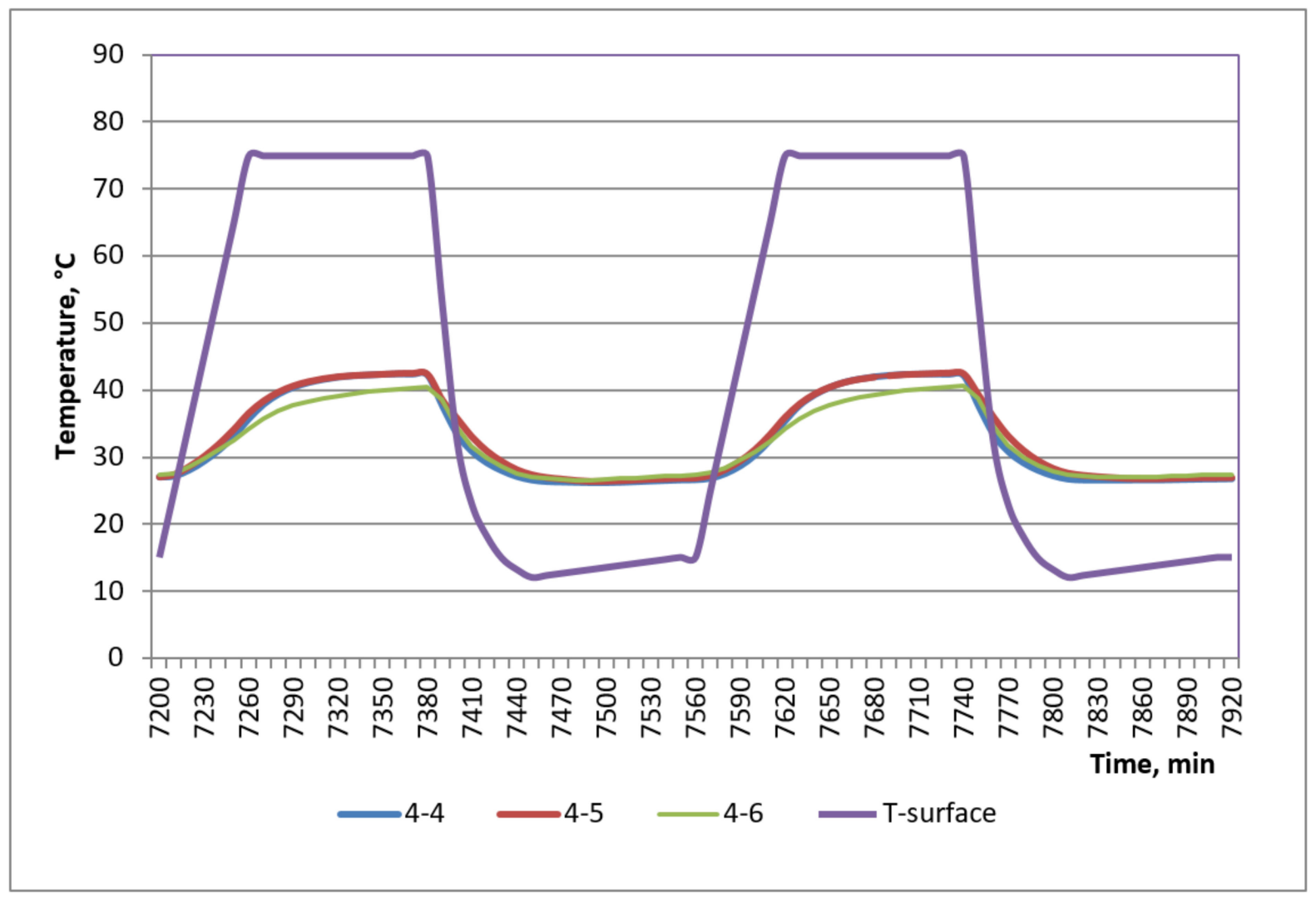

Figure 5. Temperature variation in ETICS fragment layers during hygrothermal cycles: (4-4) temperature in the middle of mineral wool; (4-5) temperature at the junction of mineral wool and polystyrene foam, (4-6) temperature in the middle of polystyrene foam. 


\subsection{Bond Strength}

After the hygrothermal cycle had ended, the obtained adhesion strength was $0.11 \mathrm{MPa}$. This was measured at the points where pulling was performed from the polystyrene foam; at the points where pulling was performed from the mineral wool, adhesion strength was $0.1 \mathrm{MPa}$; when measuring connections between polystyrene foam and mineral wool, such pulling pressure stood at $-0.05 \mathrm{MPa}$ (Table 3, Figure 6). Test results showed that the joints of EPS/MW had approximately half the bond strength of that of EPS. This was evident at the intersection of the two substances, polystyrene and mineral wool.

Table 3. Results of adhesion-strength tests of mineral wool, EPS, and joints between EPS and MW with base layer after hygrothermal cycles (touch drying, cooling-heating).

\begin{tabular}{cccc}
\hline & \multicolumn{2}{c}{ Adhesion Strength after Hygrothermal Cycles } & \\
\hline \multirow{2}{*}{ System } & Place & Average Value, MPa & Rupture Description \\
\hline \multirow{2}{*}{ ETICS no. 1 } & From EPS & 0.11 & cohesive \\
\cline { 2 - 4 } & At the joint EPS/MW & 0.05 & cohesive \\
\hline \multirow{2}{*}{ ETICS no. 2 } & From MW & 0.01 & cohesive \\
& From EPS & 0.11 & cohesive \\
\cline { 2 - 4 } & At the joint EPS/MW & 0.05 & cohesive \\
\hline \multirow{2}{*}{ ETICS no. 3 } & From MW & 0.01 & cohesive \\
& From EPS & 0.10 & cohesive \\
\cline { 2 - 4 } & At the joint EPS/MW & 0.05 & cohesive \\
\hline \multirow{2}{*}{ ETICS no. 4 } & From MW & 0.01 & cohesive \\
& From EPS & 0.10 & cohesive \\
\cline { 2 - 4 } & At the joint EPS/MW & 0.05 & cohesive \\
\hline & From MW & 0.01 & cohesive \\
\hline
\end{tabular}

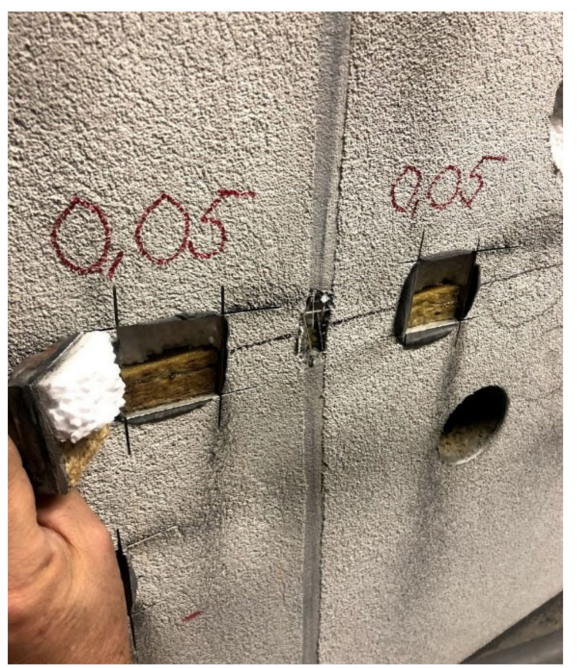

Figure 6. Testing of the bond strength of ETICS: an example of the typical pull-off at the joint of EPS/MW.

\subsection{Impact Resistance}

Following the impact-resistance experiments, results indicated that the type and size of damage have practically no influence on the type of thermoinsulating material, EPS or MW. Moreover, the joints of these materials (EPS/MW) showed no movement. However, where thermal insulation material-mineral wool (MW) and two thermal-insulation material 
were connected (EPS/MW)—impacted the ETICS samples, caused less damage compared to the impact where only polystyrene foam was used. In the case of ETICS no. 3 (mineral render), damage was greater when the base layer was applied on EPS, and in places where there is mineral wool and at the joints, the damage was smaller or nonexistent. The results of impact-resistance testing are given in Table 4; examples of the typical hard body impact on EPS and on the joint of EPS/MW are shown in Figure 7.

Table 4. Results of hard-body impact tests on EPS, MW, and on junctions of EPS/MW.

\begin{tabular}{|c|c|c|c|}
\hline Place No & $\begin{array}{l}10 \mathrm{~J} \text { Impact from a Height of } \\
1.02 \mathrm{~m} \text { (EPS) } \\
\text { Explanation/Diameter of Damage, } \mathrm{mm}\end{array}$ & $\begin{array}{c}10 \mathrm{~J} \text { Impact from a Height of } \\
1.02 \mathrm{~m}(\mathrm{MW}) \\
\text { Explanation/Diameter of Damage, } \mathrm{mm}\end{array}$ & $\begin{array}{c}10 \mathrm{~J} \text { Impact from a Height of } \\
1.02 \mathrm{~m} \text { (EPS/MW) } \\
\text { Explanation/Diameter of Damage, } \mathrm{mm}\end{array}$ \\
\hline \multicolumn{4}{|c|}{ ETICS No. 1} \\
\hline 1. & Not penetrated/41 & Not penetrated/37 & Not penetrated/42 \\
\hline 2. & Not penetrated/44 & Not penetrated/40 & Not penetrated/47 \\
\hline 3. & Not penetrated/37 & Not penetrated/42 & Not penetrated/36 \\
\hline 4. & Not penetrated/39 & Not penetrated/35 & Not penetrated/45 \\
\hline 5. & Not penetrated/48 & Not penetrated/43 & Not penetrated/41 \\
\hline \multicolumn{4}{|c|}{ ETICS No. 2} \\
\hline 1. & No deterioration/30 & No deterioration & Not penetrated/31 \\
\hline 2. & No deterioration/27 & No deterioration & No deterioration/39 \\
\hline 3. & Not penetrated/36 & No deterioration & Not penetrated/40 \\
\hline 4. & Not penetrated/37 & No deterioration & Not penetrated/38 \\
\hline 5. & Not penetrated/48 & No deterioration & Not penetrated/43 \\
\hline \multicolumn{4}{|c|}{ ETICS No. 3} \\
\hline 1. & Not penetrated/40 & No deterioration/33 & No deterioration/44 \\
\hline 2. & Not penetrated/42 & No deterioration $/ 28$ & No deterioration/39 \\
\hline 3. & Not penetrated/46 & No deterioration & No deterioration \\
\hline 4. & Not penetrated/33 & No deterioration & No deterioration \\
\hline 5. & Not penetrated/47 & No deterioration & No deterioration \\
\hline \multicolumn{4}{|c|}{ ETICS No. 4} \\
\hline 1. & Not penetrated/38 & Not penetrated/40 & Not penetrated/41 \\
\hline 2. & Not penetrated/37 & Not penetrated/40 & Not penetrated/43 \\
\hline 3. & Not penetrated/40 & Not penetrated/38 & Not penetrated/39 \\
\hline 4. & Not penetrated/39 & Not penetrated/42 & Not penetrated/33 \\
\hline 5. & Not penetrated/33 & Not penetrated/39 & Not penetrated/35 \\
\hline
\end{tabular}

Explanation: No deterioration, superficial damage, provided there was no cracking; not penetrated, superficial damage, circular cracking did not reach the insulation product.

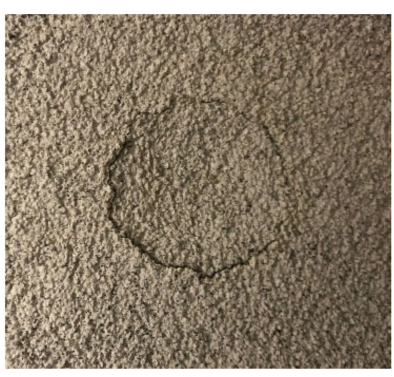

(a)

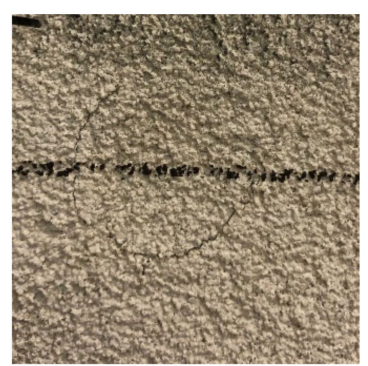

(b)

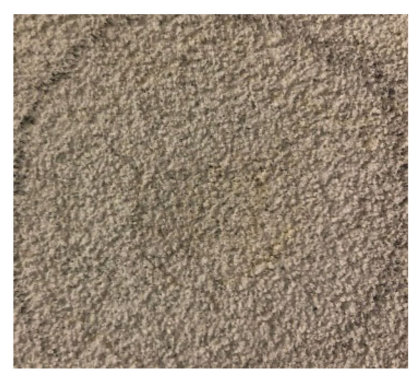

(c)

Figure 7. Hard-body impact testing: example of typical hard-body impact on (a) ETICS no2:.EPS, (b) joint of EPS/MW, (c) MW. 


\section{Conclusions}

In this study, the performance of a sample of ETICS without additional reinforcement mesh in base coat of the fire barriers was rigorously tested. This included the effects of temperature changes, dynamic moisture fluctuations (hygrothermal cycles), impact-load durability, and resistance of fire barriers, all as part of the study of overall service life. The following conclusions were drawn.

The joints of polystyrene and mineral wool had approximately half of their bond strength from polystyrene. The hard-body impacts to all tested ETICS were similar on all analysed types of thin-layer render surfaces. Only in the case of ETICS no. 3 (mineral render) was the damage greater when the base layer was applied on EPS, and in places where there was mineral wool and at the joints, the damage was smaller or nonexistent.

There were no visible defects on the external rendering layer of ETICS following the hygrothermal tests. EPS insulation with a layer of horizontal MW strips, located within the solid wall and wall openings, showed reasonable resistance to the hygrothermal cycle. Results allowed for a safe prediction of ETICS behaviour when subjected to weathering and performance (over time). All tested systems showed satisfactory behaviour during and after accelerated artificial ageing, which indicated the fact that durability was ensured, especially given their difficult access for maintenance or replacement. This also increased its longevity, thus achieving a higher sustainability index. Therefore, high-quality ETICS present good durability overall, on top of their expected thermal performance.

The tests demonstrated only a slight variation in the temperature difference within the wafered wall panels $\left(<1^{\circ} \mathrm{C}\right)$. This took place despite a clear temporary temperature difference on the surfaces in the areas of polystyrene and mineral wool, related to their density. Analysis of the measurement results showed that the horizontal strip of mineral wool used in the ETICS thermal-insulation system should not cause significant changes in the thermal-protection status of external walls in summer.

In conclusion, this study is a solid contribution to the existing body of knowledge related to similar studies of ETICS. Results satisfy energy efficiency and resilience in the modern building industry, and in attaining practical, long-lasting cladding systems for end users.

Author Contributions: All authors contributed equally to this work. All authors discussed the results and commented on the manuscript at all stages. R.N. and A.B. prepared the methodology of hygrothermal-behaviour testing and performed the experiments; P.K. and R.N. analysed the data and results. R.N. and V.B. wrote, supervised, and reviewed the paper. All authors have read and agreed to the published version of the manuscript.

Funding: This research received no external funding.

Institutional Review Board Statement: Not applicable.

Informed Consent Statement: Not applicable.

Data Availability Statement: Not applicable.

Conflicts of Interest: The authors declare that there is no conflict of interest regarding the publication of this paper.

\section{References}

1. Daniotti, B.; Paolini, R. Evolution of degradation and decay in performance of ETICS. In Proceedings of the 11th International Conference on Durability of Building Materials and Components, Istanbul, Turkey, 11-14 May 2008; p. 42.

2. Gaciek, P.; Gaczek, M.; Garecki, M. Sposoby mocowania ociepleń do powierzchni ścian według technologii ETICS. Izolacje 2018, $23,20-22$.

3. Liismaa, E.; Sepria, R.; Raadob, L.-M.; Lillc, I.; Wittd, E.D.Q.; Sulakatkoc, V.; Põldarua, M. Defect analysis of renovated facade walls with etics solutions in cold climate conditions. In Proceedings of the CESB16: Central Europe towards Sustainable Building, Prague, Czech Republic, 22-24 June 2016. 
4. Pečur, I.B.; Bjegović, D.; Boström, L.; Milovanović, B. ETICS Fire Performance Test. In Proceedings of the Fifth International Workshop on Performance, Protection \& Strengthening of Structures Under Extreme Loading, East Lansing, MI, USA, 28-30 June 2015; Available online: https:/ / www.researchgate.net/publication/280385277_ETICS_Fire_Performance_Test (accessed on 15 December 2018).

5. Sulakatko, V.; Liisma, E.; Soekov, E. Increasing construction quality of external thermal insulation composite system (ETICS) by revealing on-site degradation factors. Procedia Environ. Sci. 2017, 38, 765-772. [CrossRef]

6. Sulakatko, V.; Vogdt, F. Construction process technical impact factors on degradation of the external thermal insulation composite system. Sustainability 2018, 10, 3900. [CrossRef]

7. Barreira, E.; de Freitas, V.P. Experimental study of the hygrothermal behaviour of external thermal insulation composite systems (ETICS). Build. Environ. 2013, 63, 31-39. [CrossRef]

8. Liisma, E.; Lõhmus, G.; Raado, L. The effect of temperature and humidity on the permanence of external thermal insulation composite systems. Procedia Eng. 2015, 108, 340-348. [CrossRef]

9. Šadauskienè, J.; Buska, A.; Ramanauskas, J.; Algimantas, V. Analysis of fire spread prevention measures in ETICS and their influence on durability. J. Sustain. Archit. Civil Eng. 2016, 17, 33-44. Available online: https://www.ceeol.com/search/articledetail?id=570694 (accessed on 20 December 2020).

10. Steinbauer, V.; Kaufmann, J.; Zurbriggen, R.; Bühler, T.; Herwegh, M. Tracing hail stone impact on external thermal insulation composite systems (ETICS)—An evaluation of standard admission impact tests by means of high-speed-camera recordings. Int. J. Impact Eng. 2017, 109, 354-365. [CrossRef]

11. Barreira, E.; de Freitas, V.P. External thermal insulation composite systems: Critical parameters for surface hygrothermal behaviour. Adv. Mater. Sci. Eng. 2014, 2014, 1-16. [CrossRef]

12. Barreira, E.; de Freitas, V.P. Importance of thermography in the study of etics finishing coatings degradation due to algae and mildew growth. In Proceedings of the 10DBMC International Conference on Durability of Building Materials and Components, Lyon, France, 17 April 2005.

13. Mandilaras, I.; Atsonios, I.; Zannis, G.; Founti, M. Thermal performance of a building envelope incorporating ETICS with vacuum insulation panels and EPS. Energy Build. 2014, 85, 654-665. [CrossRef]

14. Kvande, T.; Bakken, N.; Bergheim, E.; Thue, J. Durability of ETICS with rendering in Norway—Experimental and field investigations. Buildings 2018, 8, 93. [CrossRef]

15. Sulakatko, V.; Lilla, I.; Witta, E. Methodological framework to assess the significance of External Thermal Insulation Composite System (ETICS) on-site activities. In Energy Procedia, Proceedings of the SBE16 Tallinn and Helsinki Conference: Build Green and Renovate Deep, Tallinn and Helsinki, Finland, 5-7 October 2016; Elsevier: Amsterdam, The Netherlands, 2016; Volume 96, pp. 446-454.

16. Steidl, T.; Krause, P. Moisture Transport in Cellular Concrete Walls with the Connector for Thermal Insulation. Periodica Polytech. Civil Eng. 2018, 62, 986-991. [CrossRef]

17. Uygunoğlu, T.; Özgüven, S.; Çalış, M. Effect of plaster thickness on performance of external thermal insulation cladding systems (ETICS) in buildings. Constr. Build. Mater. 2016, 122, 496-504. [CrossRef]

18. Norvaišienè, R.; Griciutè, G.; Bliūdžius, R.; Ramanauskas, J. The changes of moisture absorption properties during the service life of external thermal insulation composite system. Mater. Sci. 2013, 19, 103-107. [CrossRef]

19. European Organisation for Technical Approvals. ETAG 004 Guideline for European Technical Approval of External Thermal Insulation Composite Systems with Rendering; European Technical Approval Guideline No 004 (ETAG 004), edition 2013, used as European Assessment Document (EAD); European Organisation for Technical Approvals: Brussels, Belgium, 2013.

20. Protection Contre L'incendie des Façades Béton ou Maçonnerie Revêtues de Systèmes D'isolation Thermique Extérieure par Enduit sur Polystyrène Expansé (ETICS-PSE). Guide De Préconisations April 2016, p. 11. Available online: https: / www.sto.fr/ media/documents/ETICS_PSE_Guide_V2_septembre_2020.pdf (accessed on 20 March 2021). 